\title{
The Effect of Varying Sodium Loads on the Ileal Excreta of Human Ileostomized Subjects *
}

\author{
Philip Kramer $\dagger$ \\ (From the Evans Memorial Department of Clinical Research, University Hospital, \\ Boston, Mass.)
}

Balance studies in healthy subjects with wellestablished ileostomies have demonstrated that 30 to $90 \mathrm{mEq}$ per day of sodium is excreted in the ileal dejecta $(1-10)$. In a prior investigation we found a mean sodium excretion of $60.3 \mathrm{mEq}$ per day (11). To determine whether the ileal sodium loss can be altered by varying the amount of sodium ingested, different sodium loads were administered orally to ileostomized subjects. Experimental data of this nature are not available in man.

\section{Methods}

Three female subjects (M.C., aged 36; M.O., aged 28; and J.B., aged 34) with normal functioning ileostomies participated in the studies. An ileostomy and colectomy had been performed on each for ulcerative colitis 3 to 6 years before. The procedure previously used to study ileostomized individuals (11) was modified for the proper execution of the present investigation.

Our subjects lived at home and performed their normal activities. All studies were conducted during the winter months so as to minimize water and electrolyte losses by perspiration. Four different sodium regimens, each of which lasted 6 days, were administered. One contained that amount obtained from the basic low sodium diet alone; in the others, 4.0, 9.0, and $15.0 \mathrm{~g}$ per day of sodium chloride were added to the basic diet. Therefore, the sodium intake per day was $9,77,161$, and $262 \mathrm{mEq}$, respectively. These particular quantities were selected because they represented a low sodium intake, the average amount lost in the ileal excreta, the amount contained in a normal diet, and an excessive intake. The sodium chloride was weighed out into small paper envelopes, each of which contained the supply for the day; the salt was then added to the meals in the course of the day. The 77 and $161 \mathrm{mEq}$ per day sodium studies were conducted sequentially beginning with the smaller quan-

* Submitted for publication May 17, 1966; accepted July 28, 1966.

This investigation was supported by U. S. Public Health Service research grant AM 03560 from the National Institute of Arthritis and Metabolic Diseases.

† Address requests for reprints to Dr. Philip Kramer, University Hospital, 750 Harrison Ave., Boston, Mass. tity. Otherwise, intervals on a normal sodium intake separated the study periods.

A low sodium diet calculated to yield a daily intake of approximately $200 \mathrm{mg}$ or $9 \mathrm{mEq}$ of sodium was selected by each subject according to personal preference. The values for the caloric, carbohydrate, fat, protein, sodium, and potassium content of foods were obtained $(12,13)$. Once the diet was chosen by each subject it remained the same for the four different sodium regimens. The menu was not identical for each day of a study period, but the same foods and beverages were consumed on the corresponding day of each of the four regimens. The daily liquid intake remained constant. Each item of food or drink ingested was weighed in grams on a dietary scale by each subject, and the amount was recorded on daily intake sheets. In this way it was possible to determine the care with which the dietary regimens were followed during the four study periods. Only minor deviations in the diet occurred when the different study periods were compared; none of these deviations could possibly account for the results obtained.

Ileal excreta were passed into plastic ileostomy bags, and the urine into sodium-free plastic bottles. Collection of the ileal dejecta and urine would start each day at the same hour; the subjects would also weigh themselves. Small portable refrigerators were furnished to store the ileal excreta, which were then conveyed to our laboratory in insulated coolers. During the $9 \mathrm{mEq}$ per day study, blood pressure and pulse were determined daily in the sitting and standing positions; blood urea nitrogen and serum sodium, potassium, carbon dioxide, and chloride were measured on the first, third, and sixth days.

Ileal excreta were analyzed for total weight, dry weight, water content, sodium, fat, and nitrogen by the methods previously described (11). Concentrations of sodium and potassium were expressed in milliequivalents per kilogram of total weight of dejecta and milliequivalents per liter of the supernatant fluid. Urinary sodium and potassium were determined in a Baird flame photometer KY-1 (14). Standard statistical methods ${ }^{1}$ were used to calculate and evaluate the significance of the results. A mean for the 6-day collections for each subject and for the group on each of the sodium regimens was calculated and expressed as the mean $\pm 1 \mathrm{SD}$. The mean results obtained during each regimen were com-

1 Statistical analyses were performed by the Biostatistics Laboratory, Boston University Medical Center. 


\section{ILEAL EXCRETA}

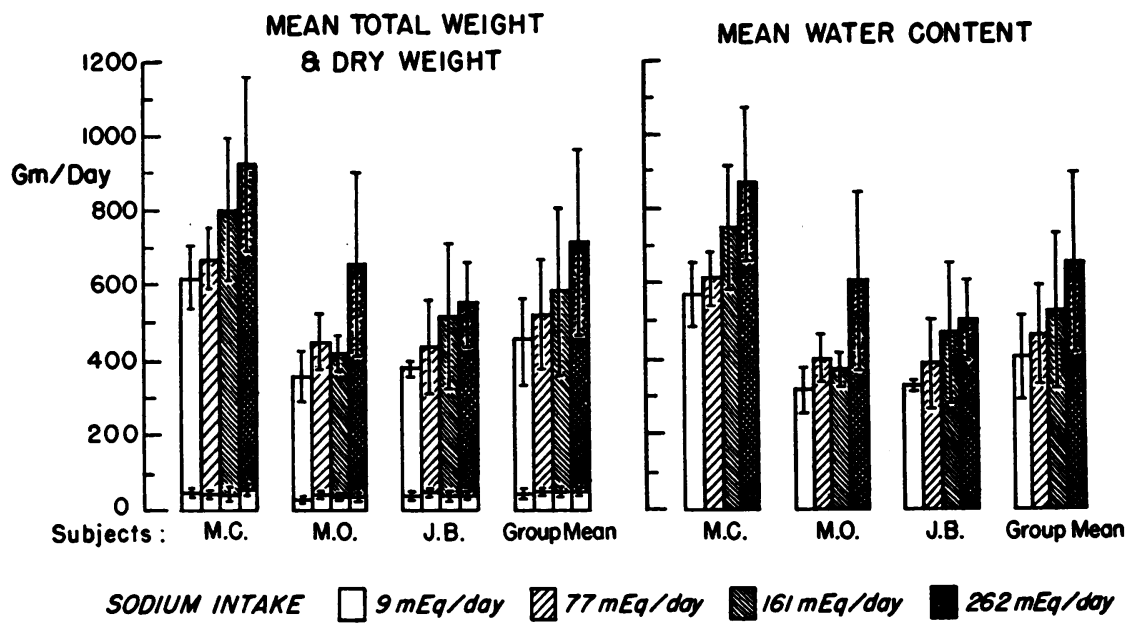

Fig. 1. The efFect of INCREASING QUANTItIES OF INGESTED SODIUM UPON The GROSS CHARACTERISTICS OF ILEAL EXCRETA IN EACH SUBJECT AND THE GROUP. The group mean total weight and mean water content rose, whereas the mean dry weight remained relatively constant. The ileal dry weight is represented by the short blank bars at the bottom of the bar graphs in the left half of the Figure. Brackets enclose the mean $\pm 1 \mathrm{SD}$.

pared; a $\mathrm{p}$ value of 0.02 or less was considered to demonstrate a significant change.

\section{Results}

The data are presented in Table I and Figures 1 to 5 .

A) Ileal excreta: gross and chemical characteristics

1) Total weight (Figure 1). The mean total weight per day of the ileal excreta was lowest on the $9 \mathrm{mEq}$ sodium regimen. With larger amounts of sodium the total weight rose correspondingly in each subject, except that in M.O. the ileal output was slightly greater on the $77 \mathrm{mEq}$ per day than on $162 \mathrm{mEq}$ per day sodium intake. When the mean values for the group were calculated, a progressive increase in total weight was likewise noted as more and more sodium was taken. Thus, the mean total weights in grams per day were $451.2 \pm 146.40,516.1 \pm 141.3,576.7 \pm 221.8$, and $706.2 \pm 246.5$ on the $9,77,161$, and $262 \mathrm{mEq}$ per day sodium regimens, respectively. The mean results for the group on the 9 and $77 \mathrm{mEq}$ per day regimens differed significantly from those on the $262 \mathrm{mEq}$ sodium load.
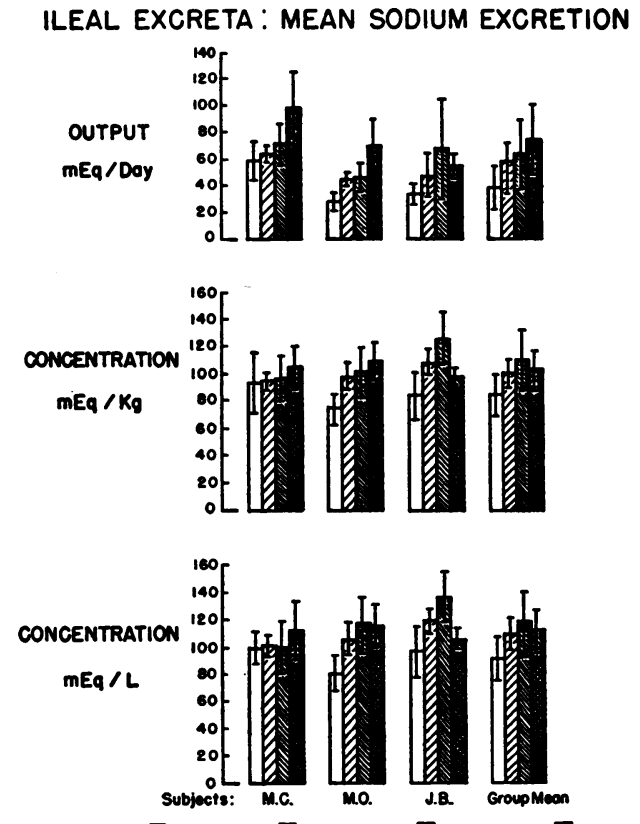

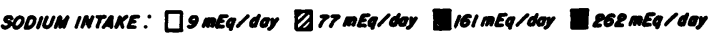

Fig. 2. Changes in the ileal mean sodium output AND CONCENTRATION AS THE SODIUM LOAD IS PROGRESSIVELY AUGMENTED. The group mean sodium output steadily increased. The mean sodium concentrations were lowest on the $9 \mathrm{mEq}$ per day sodium regimen; they did not differ significantly from each other on the other regimens. 


\begin{tabular}{|c|c|c|c|c|c|c|c|c|c|}
\hline \multirow{2}{*}{$\begin{array}{c}\begin{array}{c}\text { Sodium } \\
\text { intake }\end{array} \\
m E q / d a y\end{array}$} & \multirow{2}{*}{$\begin{array}{l}\text { Statistical } \\
\text { data and } \\
\text { p values* } \\
\text { between } \\
\text { regimens }\end{array}$} & \multirow{2}{*}{$\begin{array}{c}\text { Total } \\
\text { weight }\end{array}$} & \multicolumn{7}{|c|}{ Ileostomy excreta } \\
\hline & & & \multicolumn{2}{|c|}{ Dry weight } & \multicolumn{2}{|c|}{ Water content } & \multicolumn{3}{|c|}{ Sodium } \\
\hline $\begin{array}{c}m E q / d a y \\
9\end{array}$ & $\begin{array}{l}\text { Mean } \\
\text { SD }\end{array}$ & $\begin{array}{c}g / d a y \\
451.2 \\
\pm 146.40\end{array}$ & $\begin{array}{c}\text { g/day } \\
41.2 \\
\pm 7.59\end{array}$ & $\begin{array}{c}\% \\
9.6 \\
\pm 1.46\end{array}$ & $\begin{array}{c}\text { g/day } \\
409.6 \\
\pm 116.30\end{array}$ & $\begin{array}{c}\% \\
90.4 \\
\pm 1.46\end{array}$ & $\begin{array}{c}m E q / d a y \\
37.8 \\
\pm 15.93\end{array}$ & $\begin{array}{c}m E q / \mathrm{kg} \\
82.4 \\
\pm 14.47\end{array}$ & $\begin{array}{c}m E q / L \\
92.4 \\
\pm 15.57\end{array}$ \\
\hline 77 & $\begin{array}{l}\text { Mean } \\
\text { SD }\end{array}$ & $\begin{array}{c}516.1 \\
\pm 141.33\end{array}$ & $\begin{array}{c}45.3 \\
\pm 5.91\end{array}$ & $\begin{array}{c}9.1 \\
\pm 1.80\end{array}$ & $\begin{aligned} & 470.8 \\
\pm & 137.44\end{aligned}$ & $\begin{array}{c}90.9 \\
\pm 1.80\end{array}$ & $\begin{array}{c}50.7 \\
\pm 12.85\end{array}$ & $\begin{array}{c}99.3 \\
\pm 9.46\end{array}$ & $\begin{array}{c}109.1 \\
\pm 11.65\end{array}$ \\
\hline 161 & $\begin{array}{l}\text { Mean } \\
\text { SD }\end{array}$ & $\begin{array}{c}576.7 \\
\pm 221.76\end{array}$ & $\begin{array}{c}41.0 \\
\pm 10.04\end{array}$ & $\begin{array}{c}7.7 \\
\pm 2.11\end{array}$ & $\begin{aligned} & 535.6 \\
\pm & 214.98\end{aligned}$ & $\begin{array}{c}92.3 \\
\pm 2.11\end{array}$ & $\begin{array}{c}61.8 \\
\pm 25.41\end{array}$ & $\begin{array}{c}108.8 \\
\pm 21.05\end{array}$ & $\begin{array}{c}118.0 \\
\pm 23.29\end{array}$ \\
\hline \multirow[t]{2}{*}{262} & $\begin{array}{l}\text { Mean } \\
\text { SD }\end{array}$ & $\begin{array}{c}706.2 \\
\pm 246.54\end{array}$ & $\begin{array}{c}45.2 \\
\pm 6.33\end{array}$ & $\begin{array}{c}6.8 \\
\pm 1.46\end{array}$ & $\begin{array}{c}661.0 \\
\pm 238.77\end{array}$ & $\begin{array}{c}93.3 \\
\pm 1.28\end{array}$ & 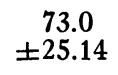 & $\begin{array}{c}102.9 \\
\pm 12.27\end{array}$ & $\begin{array}{c}111.8 \\
\pm 15.26\end{array}$ \\
\hline & $\begin{array}{r}9 \text { and } 77 \dagger \\
9 \text { and } 161 \\
9 \text { and } 262 \\
77 \text { and } 161 \\
77 \text { and } 262 \\
161 \text { and } 262\end{array}$ & $\begin{array}{l}<0.001 \\
<0.01\end{array}$ & & $\begin{array}{l}<0.01 \\
<0.001 \\
<0.05 \\
<0.001\end{array}$ & $\begin{array}{l}<0.001 \\
<0.001 \\
<0.001\end{array}$ & $\begin{array}{l}<0.01 \\
<0.001 \\
<0.05 \\
<0.001\end{array}$ & $\begin{array}{l}<0.02 \\
<0.01 \\
<0.001 \\
\\
<0.01 \\
<0.05\end{array}$ & $\begin{array}{l}<0.001 \\
<0.001 \\
<0.001\end{array}$ & $\begin{array}{l}<0.01 \\
<0.001 \\
<0.001\end{array}$ \\
\hline
\end{tabular}

$* \mathrm{p}$ values of $<0.05$ or less are listed.

$\dagger$ Numbers represent milliequivalents per day sodium intake in the various regimens.

2) Dry weight and water content. Regardless of the amount of sodium chloride administered, the dry weight remained constant (Figure 1). Consequently, the more sodium ingested the greater the mean water content of the ileal effluent. Since the total weight of ileal discharges increased because of increasing water content, the mean per cent dry weight decreased, whereas the per cent water content rose.

3) Sodium excretion (Figures 2 and 3). In spite of a sodium intake of only $9 \mathrm{mEq}$ per day, the ileal sodium excretion continued to be far in excess of this quantity; the average daily loss in each subject on this intake was $57.4 \pm 13.5 \mathrm{mEq}$ per day (M.C.), $26.5 \pm 6.6 \mathrm{mEq}$ per day (M.O.), and $32.7 \pm 7.0 \mathrm{mEq}$ per day (J.B.). The mean sodium excretion for the three subjects was $37.8 \pm$ $15.9 \mathrm{mEq}$ per day. Subject M.C. rapidly manifested symptoms and signs of sodium depletion; as a consequence, this study had to be terminated at the end of the fifth day.

With the exception of J.B., the ileal sodium excretion rose progressively as more sodium chloride was ingested. In this subject the loss was greater on the $161 \mathrm{mEq}$ per day than on the 262 $\mathrm{mEq}$ per day regimen because of an unusual sodium output on the sixth day of the former regi- men. If this day's results are excluded, then the mean loss would be the same in these two studies, i.e., $52.1 \pm 11.2 \mathrm{mEq}$ per day on $161 \mathrm{mEq}$ per day, and $53.0 \pm 9.1 \mathrm{mEq}$ on the $262 \mathrm{mEq}$ per day intake. When $262 \mathrm{mEq}$ per day of sodium was ingested, the average daily ileal sodium losses were $96.9 \pm 22.7 \mathrm{mEq}$ per day (M.C.), $69.0 \pm$ $19.0 \mathrm{mEq}$ per day (M.O.), and $53.0 \pm 9.1 \mathrm{mEq}$ per day (J.B.), with a mean for the group of 73.0 $\pm 25.1 \mathrm{mEq}$ per day. On the 77 and $161 \mathrm{mEq}$ per day sodium regimens, the mean group sodium excretions were $50.7 \pm 12.9 \mathrm{mEq}$ per day and $61.8 \pm$ $25.4 \mathrm{mEq}$ per day, respectively.

The mean ileal sodium concentration in each subject was lowest on the $9 \mathrm{mEq}$ per day intake, $91.7 \pm 22.4 \mathrm{mEq}$ per $\mathrm{kg}$ in subject M.C., $73.9 \pm$ $10.5 \mathrm{mEq}$ per $\mathrm{kg}$ in subject M.O., and $83.3 \pm 16.8$ $\mathrm{mEq}$ per $\mathrm{kg}$ in subject J.B. There were no significant differences among any of the sodium concentrations on any of the regimens in subject M.C. The mean concentrations for the group were 82.4 $\pm 14.5,99.3 \pm 9.5,108.8 \pm 21.05$, and $102.9 \pm$ $12.3 \mathrm{mEq}$ per $\mathrm{kg}$ on the $9,77,161$, and $262 \mathrm{mEq}$ per day sodium regimens, respectively. The latter three results do not differ significantly from each other, but a mean value of $82.4 \pm 14.5 \mathrm{mEq}$ per 
TABLE I

$S D$ for the group

\begin{tabular}{|c|c|c|c|c|c|c|c|c|c|}
\hline \multicolumn{5}{|c|}{ Ileostomy excreta } & \multicolumn{5}{|c|}{ Urine } \\
\hline \multicolumn{3}{|c|}{ Potassium } & Nitrogen & Fat & \multirow{2}{*}{$\begin{array}{c}\text { Volume } \\
m l / \text { day } \\
1,393.5 \\
\pm 265.29\end{array}$} & \multicolumn{2}{|c|}{ Sodium } & \multicolumn{2}{|c|}{ Potassium } \\
\hline $\begin{array}{c}m E q / d a y \\
5.13 \\
\pm 2.25\end{array}$ & $\begin{array}{r}m E q / k g \\
12.30 \\
\pm 6.29\end{array}$ & $\begin{array}{r}m E q / L \\
13.63 \\
\pm 7.09\end{array}$ & $\begin{array}{r}1.55 \\
\pm 0.32\end{array}$ & $\begin{array}{r}2.00 \\
\pm 0.79\end{array}$ & & $\begin{array}{c}m E q / d a y \\
27.2 \\
\pm 38.50\end{array}$ & $\begin{array}{c}m E q / L \\
17.1 \\
\pm 20.06\end{array}$ & $\begin{array}{c}m E q / d a y \\
104.1 \\
\pm 31.05\end{array}$ & $\begin{array}{c}m E q / L \\
76.2 \\
\pm 23.72\end{array}$ \\
\hline $\begin{array}{r}4.10 \\
\pm 1.03\end{array}$ & $\begin{array}{r}8.17 \\
\pm 2.56\end{array}$ & $\begin{array}{r}9.03 \\
\pm 2.38\end{array}$ & $\begin{array}{r}1.53 \\
\pm 0.51\end{array}$ & $\begin{array}{r}2.21 \\
\pm 1.01\end{array}$ & $\begin{array}{l}1,190.6 \\
\pm 287.86\end{array}$ & $\begin{array}{c}53.5 \\
\pm 38.22\end{array}$ & 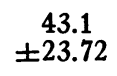 & $\begin{array}{c}105.3 \\
\pm 18.45\end{array}$ & $\begin{array}{c}95.9 \\
\pm 22.54\end{array}$ \\
\hline $\begin{array}{r}4.75 \\
\pm 1.49\end{array}$ & $\begin{array}{r}8.65 \\
\pm 1.98\end{array}$ & $\begin{array}{r}9.30 \\
\pm 2.13\end{array}$ & $\begin{array}{r}1.54 \\
\pm 0.47\end{array}$ & $\begin{array}{r}2.21 \\
\pm 1.06\end{array}$ & $\begin{array}{c}961.4 \\
\pm 221.98\end{array}$ & $\begin{array}{c}89.7 \\
\pm 47.50\end{array}$ & $\begin{array}{c}93.2 \\
\pm 41.37\end{array}$ & $\begin{array}{c}104.9 \\
\pm 10.69\end{array}$ & $\begin{array}{c}114.4 \\
\pm 27.12\end{array}$ \\
\hline $\begin{array}{r}4.48 \\
\pm 2.00\end{array}$ & $\begin{array}{r}6.37 \\
\pm 2.22\end{array}$ & $\begin{array}{r}6.77 \\
\pm 2.43\end{array}$ & $\begin{array}{r}1.77 \\
\pm 0.29\end{array}$ & $\begin{array}{r}2.60 \\
\pm 1.36\end{array}$ & $\begin{array}{c}908.1 \\
+215.69\end{array}$ & $\begin{aligned} & 34.9 \\
+ & 53.45\end{aligned}$ & $\begin{array}{c}143.4 \\
\pm 36.53\end{array}$ & $\begin{array}{c}105.1 \\
\pm 25.65\end{array}$ & $\begin{array}{c}115.1 \\
\pm 22.51\end{array}$ \\
\hline & $\begin{array}{l}<0.05 \\
<0.02 \\
<0.02\end{array}$ & $\begin{array}{l}<0.02 \\
<0.02 \\
<0.01 \\
<0.01 \\
<0.01\end{array}$ & $<0.05$ & & $\begin{array}{l}<0.05 \\
<0.001 \\
<0.001 \\
<0.02 \\
<0.01\end{array}$ & $\begin{array}{l}<0.001 \\
<0.001 \\
<0.02 \\
<0.001 \\
<0.02\end{array}$ & $\begin{array}{l}<0.001 \\
<0.001 \\
<0.001 \\
<0.001 \\
<0.001 \\
<0.001\end{array}$ & & $\begin{array}{l}<0.02 \\
<0.001 \\
<0.001 \\
<0.05 \\
<0.02\end{array}$ \\
\hline
\end{tabular}

$\mathrm{kg}$ represents a significant difference from each of the other means, $\mathrm{p}<0.001$.

The sodium concentrations, when expressed in milliequivalents per liter rather than milliequivalents per kilogram, showed similar numerical and statistical trends, although the individual numerical figures were greater. For the group, the mean results on the $9,77,161$, and $262 \mathrm{mEq}$ per day sodium loads were $92.4 \pm 15.6,109.1 \pm 11.7,118.0$ \pm 23.3 , and $111.8 \pm 15.3 \mathrm{mEq}$ per $\mathrm{L}$.

4) Potassium excretion (Figure 4). Mean potassium excretions per day were quite similar irrespective of the sodium loads in each of the subjects or in the whole group. On the other hand, the mean potassium concentration was highest on the $9 \mathrm{mEq}$ per day sodium intake in each subject and in the group. Considerable variations in the mean results in each subject were obtained on the other regimens. However, the group mean potassium concentration decreased from 12.3 \pm $6.3 \mathrm{mEq}$ per $\mathrm{kg}$ on the $9 \mathrm{mEq}$ per day sodium regimen to $6.37 \pm 2.2 \mathrm{mEq}$ per $\mathrm{kg}$ on the 262 $\mathrm{mEq}$ per day intake.

Presentation of the data by describing the mean values obscures a noteworthy phenomenon. During the $9 \mathrm{mEq}$ per day study, the ileal excreta potassium output (milliequivalents per day) and concentration rose almost daily in each individual. Subject M.O. particularly illustrated these changes (Figure 5). On the first day the potassium output was $1.61 \mathrm{mEq}$ per day and the concentration was $5.3 \mathrm{mEq}$ per $\mathrm{kg}$; on the third day, these values were 4.03 and 9.9 ; on the fifth day, 5.24 and 18.5 ; and on the sixth day, 8.20 and 23.3. Such changes did not occur on the larger sodium intakes.

5) Nitrogen excretion. The mean nitrogen excretion in each subject or in the group showed little variation on the different regimens. Thus, the group mean nitrogen losses on the $9,77,161$, and $262 \mathrm{mEq}$ per day sodium intakes were $1.55 \pm$ $0.32,1.53 \pm 0.51,1.54 \pm 0.47$, and $1.77 \pm 0.29 \mathrm{~g}$ per day, respectively.

6) Fat excretion. Fat losses also did not change significantly, regardless of the sodium intake. The mean fat excretion values for the three subjects were $2.0 \pm 0.8,2.21 \pm 1.01,2.21 \pm 1.06$, and $2.60 \pm 1.36 \mathrm{~g}$ per day on the $9,77,161$, and 262 $\mathrm{mEq}$ per day sodium regimens, respectively.

\section{B) Urine}

1) Volume. The mean urine volume in each subject was largest on the $9 \mathrm{mEq}$ per day sodium regimen. It decreased as more sodium was ingested except that in M.C. and J.B. the mean urine 
DAILY SODIUM EXCRETION
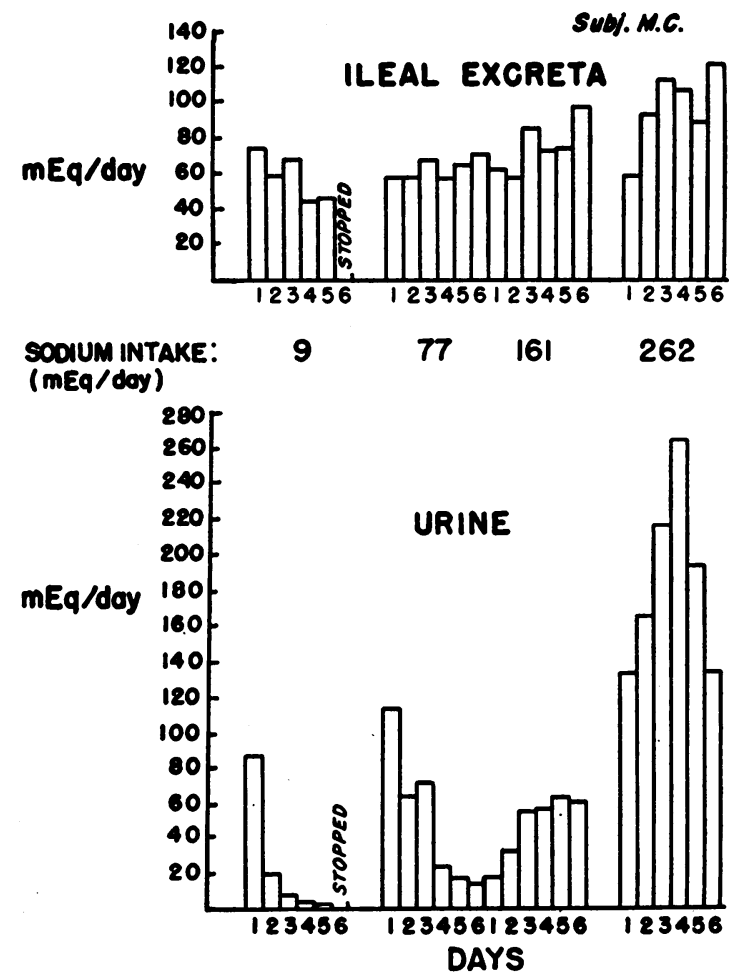

Fig. 3. DAILy SODIUM OUTPUTS IN THE ILEAL EXCRETA AND URINE WHEN VARYING SODIUM LOADS ARE ADMINISTERED TO SUBJECT M.C. Two phenomena that should be noted are: 1 ) The ileal sodium excretion continued despite a sodium intake of $9 \mathrm{mEq}$ per day; as a consequence this study had to be stopped at the end of the fifth day because of symptoms of sodium depletion. 2) The rapidity and degree with which the urinary sodium fell on the 9 and $77 \mathrm{mEq}$ per day sodium regimens.

output was greater on 161 than on $262 \mathrm{mEq}$ per day sodium. The mean urine volumes for the group were $1,390 \pm 265.3,1,190.6 \pm 287.9,961.0$ \pm 222.0 , and $908.1 \pm 215.7 \mathrm{ml}$ per day on 9,77 , 161 , and $262 \mathrm{mEq}$ per day regimens, respectively.

2) Sodium excretion. The urinary sodium excretion on the $9 \mathrm{mEq}$ per day intake fell precipitously (Figure 3 ) so that by the third day it was $9.3 \mathrm{mEq}$ per day or less in all three subjects; in J.B. it rose slightly to $12.0 \mathrm{mEq}$ on the fourth day but thereafter continued to decrease. When the low sodium study was terminated on the fifth day in M.C. and on the sixth day in M.O. and J.B., the urinary sodium excretion was $1.5,3.8$, and 7.6 $\mathrm{mEq}$ per day, respectively. The sodium concentration decreased in a parallel fashion. Similar, but not as marked, changes were noted in the daily sodium excretion on the $77 \mathrm{mEq}$ sodium regimen in subjects M.C. and M.O., so that on the sixth day the urine contained 12.8 and $19.2 \mathrm{mEq}$ per day of sodium, respectively. On the 161 and 262 $\mathrm{mEq}$ per day sodium loads, wide fluctuations were noted in both the daily sodium excretion and concentration.

3) Potassium excretion. On the whole, the urinary potassium losses remained fairly constant, regardless of the amount of sodium ingested, except on the $262 \mathrm{mEq}$ per day regimen. In M.O. the mean potassium excretion fell to $75.1 \mathrm{mEq}$ per day and in J.B. it rose to 125.3. The mean potassium output for the group was 104.1 \pm 31.05 , $105.3 \pm 18.5,104.9 \pm 10.7$, and $105.1 \pm 25.7 \mathrm{mEq}$ per day starting with the smallest and ending with the largest sodium regimen.

On the other hand, the mean potassium concentration was lowest on the $9 \mathrm{mEq}$ per day regimen in each of the subjects and for the entire group. The mean values for the group were 76.2 $\pm 23.7,95.5 \pm 22.5,114.4 \pm 27.1$, and $115.1 \pm$
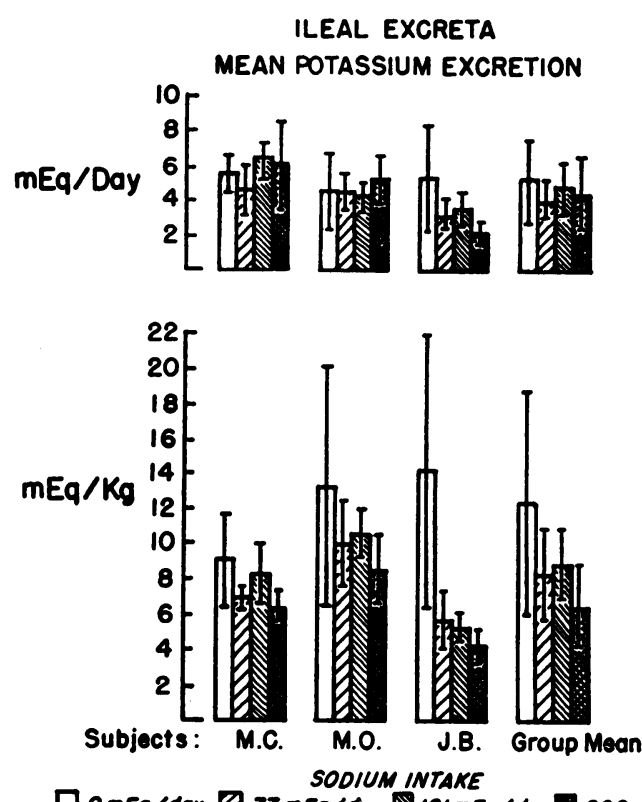

Fig. 4. Comparison of ILEAL potassium EXcretion AND CONCENTRATION WHILE THE SUBJECTS WERE ON THE VARIOUS SODIUM REGIMENS. The mean ileal potassium excretion remained the same in each subject regardless of the amount of sodium ingested. However, the mean potassium concentration was greater on the $9 \mathrm{mEq}$ per day sodium intake than on any of the other regimens. 
$22.5 \mathrm{mEq}$ per $\mathrm{L}$ on the $9,77,161$, and $262 \mathrm{mEq}$ per day sodium regimens, respectively.

\section{C) Clinical data}

On the $9 \mathrm{mEq}$ per day sodium intake, evidence of sodium depletion was noted in M.C., who had experienced the largest daily ileal sodium loss. Symptoms were noted on the third day, and by the fifth she complained of faintness when erect and cramping sensations in toes, fingers, back of the neck, and across the abdomen. When standing, her systolic blood pressure was $86 \mathrm{~mm} \mathrm{Hg}$, and the diastolic could not be detected; her pulse was 112 beats per minute. Control blood pressures and pulse rates were $108 / 68 \mathrm{~mm} \mathrm{Hg}$, left arm, sitting, 112/84, left arm, standing; and 82 beats per minute sitting, 94 standing.

No particular symptom, blood pressure, or pulse changes were observed in the other two subjects. No alterations in the blood urea nitrogen, serum sodium, potassium, carbon dioxide, and chloride occurred in any of the subjects.

M.C. lost 7 pounds, M.O. 6 pounds, and J.B. 2 pounds, during the $9 \mathrm{mEq}$ sodium regimen. These

\section{DAILY ILEAL POTASSIUM EXCRETION}
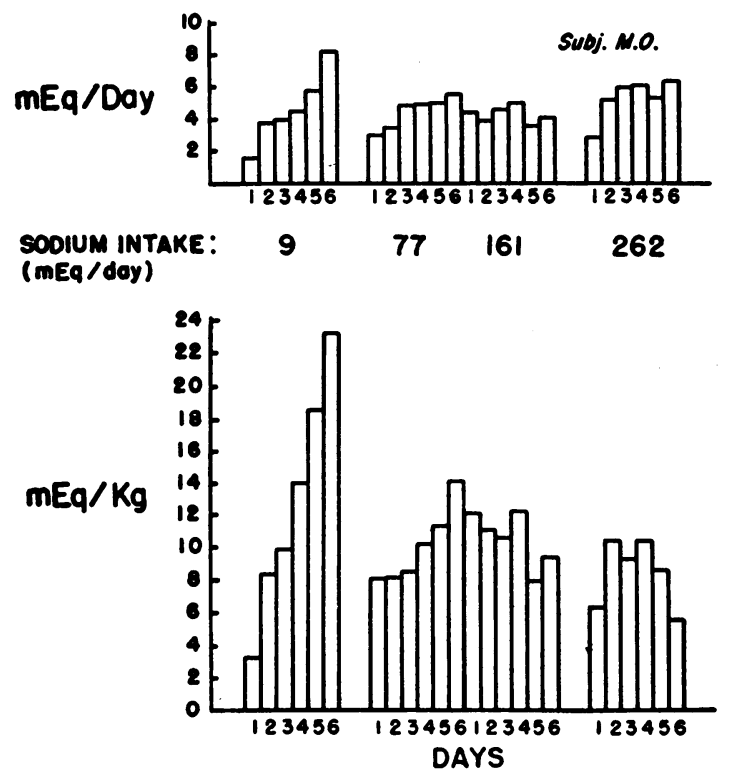

Fig. 5. Daily ileal potassium excretion and poTASSIUM CONCENTRATION IN SUBJECT M.O. The progressive daily increase in potassium output, but particularly in the concentration, on the $9 \mathrm{mEq}$ per day sodium regimen is noteworthy. weight changes were similar to those described by others in subjects on a low sodium intake. Thomas, Howard, and Isaacs (15) found that their subjects experienced a $1.4 \%$ weight loss on a chronic low salt regimen, whereas Leaf and Couter (16) reported an immediate loss of $2 \mathrm{~kg}$ within 3 to 4 days on a $9 \mathrm{mEq}$ per day sodium diet.

\section{Discussion}

Daily variations were observed in each of the measured parameters on the different sodium regimens. However, the mean results obtained on the four sodium loads in each subject showed definite and similar trends as more sodium chloride was administered. When the means for the group were analyzed, these trends became more apparent.

As larger quantities of sodium chloride were ingested, the mean total weight per day of the ileal excreta increased. This increase was due to the greater water content, since the mean dry weight per day did not change. The mean sodium excretion in milliequivalents per day varied with the amount of sodium ingested. On the other hand, except during the $9 \mathrm{mEq}$ per day sodium intake, the sodium concentrations in the ileal excreta on the different regimens were quite similar.

These results can most readily be explained by postulating that the small intestinal contents except under conditions of sodium deprivation are maintained at a relatively fixed sodium concentration. As more sodium was ingested, more was unabsorbed, but it was then excreted at this relatively fixed concentration, the excreted sodium carrying water with it. Therefore, sodium chloride apparently behaves as an osmotic cathartic and increases the ileal excreta by increasing the water content but not the solid matter.

In spite of a negative sodium balance on the 9 $\mathrm{mEq}$ sodium regimen, sodium excretion in the ileal dejecta persisted with only a moderate degree of adjustment to sodium needs. The small intestine thus appears to have a limited capacity to conserve sodium. The importance of the colon in regulating intestinal sodium excretion is thereby emphasized. Thus, patients with an intact intestinal tract and normal renal function can continue on a sodium intake of $10 \mathrm{mEq}$ per day for at least 3 to 4 months without any adverse effects (17). At the other extreme, a sodium chloride intake of 
$28.0 \mathrm{~g}$ per day (438 $\mathrm{mEq}$ sodium) did not result in an increase in sodium excretion in the feces above the normal $5 \mathrm{mEq}$ per day (16).

However, it would appear that the small bowel may partially conserve sodium by altering the sodium concentration. Thus, the mean ileal sodium concentration was $82.4 \mathrm{mEq}$ per $\mathrm{kg}$ on the $9 \mathrm{mEq}$ per day intake, as compared to $99.3 \mathrm{mEq}$ per $\mathrm{kg}$ or higher on any of the other regimens $(p<$ $0.001)$. The decrease in the sodium concentration between the 9 and $77 \mathrm{mEq}$ sodium regimens occurred because there was a disproportionate reduction of the water content $(13 \%)$ as compared with the sodium concentration $(25.4 \%)$.

A decrease in the ileal sodium concentration was observed by Field and co-workers (18) in dogs and Goodall and Kay (19) in sheep when these animals were sodium depleted. In the dog experiments, the sodium intake was reduced from 73 to $1 \mathrm{mEq}$ per day; the ileal sodium concentration fell from $78 \pm 21$ to $16 \pm 8 \mathrm{mEq}$ per $\mathrm{L}$. Goodall and Kay (19) produced sodium depletion by removing 4 to $6 \mathrm{~L}$ of saliva; the ileal sodium concentration decreased from 155 to $91 \mathrm{mEq}$ per kg water. Gallagher, Harrison, and Skyring (9) reported a sodium concentration as low as 60 $\mathrm{mEq}$ per $\mathrm{L}$ in the ileal excreta of ileostomized subjects who experienced excessive sodium losses due to diarrhea or sweating.

On the $9 \mathrm{mEq}$ per day sodium regimen the daily ileal potassium excretion and particularly the potassium concentration rose in a stepwise fashion. An increase in the ileal potassium concentration was also noted by Field and associates (from $17 \pm 6$ to $89 \pm 15 \mathrm{mEq}$ per L), Goodall and Kay (from 14 to $64 \mathrm{mEq}$ per $\mathrm{kg}$ water), and Gallagher and co-workers (to $40 \mathrm{mEq}$ per L). The changes in the ileal sodium and potassium excretion observed by these authors were quantitatively much greater than those we are reporting.

Our findings of a decrease in the mean sodium output and concentration and an increase in the daily potassium excretion and concentration during a low and inadequate sodium intake are in keeping with the suggestion by Gallagher and co-workers (9) that an increased endogenous mineralocorticoid secretion may have occurred to account for the alteration in the ileal excretion of these electrolytes. Sodium depletion is a stim- ulus to the secretion of endogenous aldosterone $(20,21)$.

Fat and nitrogen excretion were unaltered regardless of the described changes in the other parameters. General absorptive functions of the small intestine were unimpaired on any of the sodium regimens.

An inverse relationship between the mean total weight of ileal excreta and the mean urine volume occurred on the varying sodium loads. The largest urine volumes were obtained on the lowest sodium regimen. In part, this effect was due to the fact that less water was excreted in the ileal effluent; therefore, more water was available for elimination by the kidneys. Another factor was probably the excretion of the excess extracellular body water that resulted from the negative sodium balance; the weight loss the subjects experienced could be accounted for in this way.

The rapid decrease in the urinary sodium on the $9 \mathrm{mEq}$ per day regimen is worthy of comment. It reflects the fact that excessive intestinal losses of sodium are occurring. In normal intact individuals on an intake of approximately $10 \mathrm{mEq}$ per day of sodium, urinary sodium was reduced to 5 to $10 \mathrm{mEq}$ in 7 days in one study (22) and in 5 days in another (16). Our ileostomy subjects achieved this urinary level in 3 days.

The urinary sodium changes provide objective evidence regarding the validity of our methods of conducting this study, i.e., with the subjects living at home. Supporting evidence regarding this thesis is furnished by the clinical data in subject M.C., and the constancy of the dry weights on the various sodium regimens. If the diet had not been closely adhered to, none of these phenomena would have occurred. A satisfactory metabolic study therefore can be conducted in ileostomized subjects without hospitalization.

If the mean ileal sodium excretion per day is subtracted from the quantity ingested, then the net sodium absorption by the small intestine can be calculated. On the 77, 161, and $262 \mathrm{mEq}$ per day sodium regimens, during which a positive balance occurred, $26.3,99.2$, and $189.0 \mathrm{mEq}$ per day, respectively, were absorbed. These results have therapeutic implications. A net sodium absorption of $26.3 \mathrm{mEq}$ per day is too close to the borderline to guarantee a positive balance indefinitely. It would appear that an ileostomized patient who 
is not losing excessive sodium because of diarrhea should consume about 6.0 to $9.0 \mathrm{~g}$ per day of sodium chloride. These quantities would promote an adequate positive sodium balance without making the ileostomy discharges too watery.

\section{Summary}

Different amounts of sodium, 9, 77, 161, and $262 \mathrm{mEq}$ per day, were administered orally to three healthy ileostomized subjects. Each study period lasted 6 days.

The small intestine has a limited capacity to conserve sodium. Thus, on the $9 \mathrm{mEq}$ per day sodium intake sodium excretion continued via the ileostomy and far exceeded the amount ingested; the urinary sodium output fell rapidly to $10 \mathrm{mEq}$ per day or less within a 3-day period in all subjects. Because of the ileal sodium loss, clinical evidence of sodium depletion occurred in one subject. The mean ileal sodium output and concentration for the group were lowest on the $9 \mathrm{mEq}$ per day sodium intake, whereas potassium concentration and output rose; these changes suggested that an endogenous mineralocorticoid response may have occurred.

As $77 \mathrm{mEq}$ per day and the larger quantities of sodium were ingested, the ileal excreta total weight (grams per day), the water content (grams per day), and the sodium excretion (milliequivalents per day) increased, whereas the dry weight (grams per day) remained constant. However, the sodium concentration in milliequivalents per kilogram or milliequivalents per liter did not change. Such findings suggest an osmotic cathartic effect by the larger amounts of sodium chloride.

Fat and nitrogen excretion remained unchanged throughout the study.

\section{Acknowledgments}

The author acknowledges the technical assistance of Mack Duffy, Richard L. Houston, and Mary M. Kearney.

\section{References}

1. Welch, C. S., E. G. Wakefield, and M. Adams. Functions of the large intestine of man in absorption and excretion. Study of a subject with an ileostomy stoma and an isolated colon. Arch. intern. Med. 1936, 58, 1095.

2. Johnson, R. M. The absorption and excretion of calcium and phosphorus in three patients with colostomy and ileostomy. J. clin. Invest. 1937, 16, 223.

3. Lockwood, J. S., and H. T. Randall. The place of electrolyte studies in surgical patients. Bull. N. Y. Acad. Med. 1949, 25, 228.

4. MacFadyan, D. A., O. H. Akre, J. Duncan, F. Flesch, and M. Mauser. Electrolyte metabolism in ulcerative colitis patients before and after surgery. Gastroenterology 1954, 27, 544.

5. Fowler, D. I., W. T. Cooke, B. N. Brooke, and E. V. Cox. Ileostomy and electrolyte excretion. Amer. J. dig. Dis. 1959, 4, 710.

6. Smiddy, F. G., S. D. Gregory, I. B. Smith, and J. C. Goligher. Fecal loss of fluid, electrolytes and nitrogen in colitis before and after ileostomy. Lancet 1960, 1, 14.

7. Sammons, H. G. Factors affecting faecal composition-a comparison of ileal discharge and faeces. Biochem. J. 1961, 80, 30p.

8. Nuguid, T. P., H. E. Bacon, and J. Boutwell, Jr. An investigation of the volume of output and chemical content of ileal discharges following total colectomy and ileostomy. Surg. Gynec. Obstet. 1961, 113, 733.

9. Gallagher, N. D., D. D. Harrison, and A. P. Skyring. Fluid and electrolyte disturbances in patients with long-established ileostomies. Gut 1962, 3, 219.

10. Kanaghinis, T., M. Lubran, and N. F. Coghill. The composition of ileostomy fluid. Gut 1963, 4, 322.

11. Kramer, P., M. M. Kearney, and F. J. Ingelfinger. The effect of specific foods and water loading on the ileal excreta of ileostomized human subjects. Gastroenterology 1962, 42, 535.

12. Watt, B. K., and A. L. Merrill. Composition of Foods-Raw, Processed, Prepared. Washington, D. C., U. S. Department of Agriculture handbook no. 8, 1950.

13. Mattice, M. R. Bridges' Food and Beverage Analyses, 3rd ed. Philadelphia, Lea \& Febiger, 1950.

14. Flame Photometer Instruction Manual for Model KY-1. Cambridge, Baird-Atomic.

15. Thomas, C. B., E. Howard, and A. Isaacs. The effect of sodium withdrawal upon the body weight of young men. Bull. Johns Hopk. Hosp. 1949, 85, 115.

16. Leaf, A., and W. T. Couter. Evidence that renal sodium excretion by normal young subjects is regulated by adrenal cortical activity. J. clin. Invest. $1949,28,1067$.

17. Dole, V. P., L. K. Dahl, G. C. Cotzias, H. A. Eder, and M. E. Krebs. Dietary treatment of hypertension; clinical and metabolic studies of patients on the rice-fruit diet. J. clin. Invest. 1950, 29, 1189.

18. Field, H., Jr., L. Swell, R. E. Dailey, E. C. Trout, Jr., and R. S. Boyd. Electrolyte changes in ileal contents and in feces during restriction of dietary sodium with and without the administration of cation-exchange resin. Circulation 1955, 12, 625. 
19. Goodall, E. D., and R. N. B. Kay. The effect of sodium depletion and potassium supplements on the concentrations of sodium and potassium in the gut fluids of sheep. J. Physiol. (Lond.) 1965, 176, 18P.

20. Mills, J. N. Aldosterone secretion in man. Brit. med. Bull. 1962, 18, 170.

21. Binnion, P. F., J. O. Davis, T. C. Brown, and M. J.
Olichney. Mechanisms regulating aldosterone secretion during sodium depletion. Amer. J. Physiol. 1965, 208, 655.

22. Renwick, R., J. S. Robson, and C. P. Stewart. Observations upon the withdrawal of sodium chloride from the diet in hypertensive and normotensive individuals. J. clin. Invest. 1955, 34, 1037. 